\title{
CURRENT POSITION
}

Assistant professor at the Chemcail Engineering Department, An- Najah National University, August 2011 - Present

\section{EDUCATION}

- Ph.D., Polymer biomedical Materials Engineering, Wageningen University, the Netherlands, April 2005 - March 2009

Thesis title: Polylactide microcapsules and films: preparation and properties

- MS.c. Chemical process engineering "environmentally sustainable process technology", Chalmers University of Technology, Gothenburg, Sweden, September 2003 - December 2004.

- Bachelor Chemical engineering, An-Najah National University, Palestine, September 1997 - January 2002.

\section{WORK EXPERIENCE}

- Assistant professor, chemical and material engineering, An-Najah National University, Palestine, August, 2011 - present,

- $\quad$ Researcher at Wageningen University, the Netherlands, April 2009 - July 2011

- Research and teaching assistant, Wageningen University, the Netherlands, April 2005 - March 2009

\section{AWARDS and Scholarships}

- Swedish Institute Scholarship for Master Studies (2003-2005).

- Arab Student Aid International Scholarship (1999, 2000).

- Hajj Nimir Al-Tamimi Acadimic Award (1999, 2000, 2001).

\section{COURSES TAUGHT:}

\section{BACHELOR COURSES:}

- Fluid mechanics

- Polymer science

- Mass transfer 
- Separation processes

- Mathematical modelling in chemical engineering

- Petroleum engineering

\section{PUBLICATIONS}

\section{REFEREED JOURNALS:}

- Hassan Sawalha, Karin Schroën and Remko Boom, Hollow polylactide microcapsules with controlled morphology and thermal and mechanical properties. AIChE Journal, 2009. 55(11): p. 2827-2834.

- Hassan Sawalha, Karin Schroën and Remko Boom, Mechanical properties and porosity of polylactide for biomedical applications. Journal of applied polymer science, 2008. 107(1): p. 82-93.

- Hassan Sawalha, Karin Schroën and Remko Boom, Addition of oils to polylactide casting solutions as a tool to tune film morphology and mechanical properties. Polymer engineering and science, 2010, 50(3): p. 513-519.

- Hassan Sawalha, Yuxuan Fan, Karin Schroën and Remko Boom, Preparation of hollow polylactide microcapsules through premix membrane emulsification-Effects of nonsolvent properties. Journal of membrane science, 2008. 325(2): p. 665-671.

- Hassan Sawalha, Nanik Purwanti, Arjen Rinzema, Karin Schroën and Remko Boom, Polylactide microspheres prepared by premix membrane emulsification-Effects of solvent removal rate. Journal of membrane science, 2008. 310(1-2): p. 484-493.

- Hassan Sawalha, Karin Schroën and Remko Boom, Polylactide films formed by immersion precipitation: Effects of additives, nonsolvent, and temperature. Journal of applied polymer science, 2007. 104(2): p. 959-971.

- Hassan Sawalha, Paul Venema, Arjen Bot, Eckhard Flöter and Erik van der Linden, The Influence of Concentration and Temperature on the Formation of $y$-Oryzanol $+\beta$ Sitosterol Tubules in Edible Oil Organogels. Food Biophysics, 2011, 6(1): p. 20-25.

- Arjen Bot, Ruud den Adel, Christos Regkos, Hassan Sawalha, Paul Venema and Eckhard Flöter, Structuring in $\beta$-sitosterol $+\gamma$-oryzanol-based emulsion gels during various stages of a temperature cycle, Food Hydrocolloids, 2011, 25(4): p. 639-646.

- Hassan Sawalha, Karin Schroën and Remko Boom, Biodegradable polymeric microcapsules: preparation and properties. Chemical engineering journal, 2011, 169 (13). p. 1-10.

- Hassan Sawalha, Ruud den Adel, Paul Venema, Arjen Bot, Eckhard Flöter and Erik van der Linden, Organogel-emulsions with mixtures of $\beta$-sitosterol + $\gamma$-oryzanol: Influence of water activity and type of oil phase on gelling capability. Journal of Agricultural and Food Chemistry, 2012, 60 (13), p 3462-3470

- Ardy Kroes-Nijboer, Hassan Sawalha, Paul Venema, Arjen Bot, Flöter Eckhard, Ruud den Adel, Wim Bouwman and Erik Van der Linden, Formation, Structure and Properties of Fibrillar Systems, Faraday Discussions, 2012, Accepted for publication

- Arjen Bot, Elliot Paul Gilbert, Wim Bouwman, Hassan Sawalha, Ruud den Adel, Vasil Haramus, Paul Venema, Erik Van der Linden and Flöter Eckhard, Elucidation of density profile of self-assembled sitosterol + oryzanol tubules with small-angle neutron scattering, Faraday Discussions, 2012, Accepted for publication 


\section{REFEREED CONFERENCES:}

- Hassan Sawalha, Karin Schroën and Remko Boom, Preparation of Polylactide microspheres for use as ultrasound contrast agents, 8th World Biomaterials Congress, 28 May - 1 June, 2008, Amsterdam, The Netherlands.

- Hassan Sawalha, Karin Schroën and Remko Boom, Polylactide particles for ultrasound imaging, advanced nanomaterials conference, 21-25 June, 2008, Aveiro, Portugal.

- Karin Schroën, Hassan Sawalha, Remko Boom, Emulsification Technology for microbubble production, Microbubbles for ultrasound imaging and drug delivery: new applications with BURSTing bubbles, 28 November, 2008, Eindhoven, The Netherlands.

- Hassan Sawalha, Karin Schroën and Remko Boom, Preparation of polylactide ultrasound contrast agents, Netherlands Process Technology Symposium, 28-30 October, 2007, Veldhoven, The Netherlands.

- Hassan Sawalha, Karin Schroën and Remko Boom, Bubbles for ultrasound and therapy, Netherlands Process Technology Symposium, 24-25 October, 2005, Veldhoven, The Netherlands.

- Maher Al-Jabari and Hassan Sawalha, Treating Stone cutting Waste by FlocculationSedimentation, 28th WEDC Conference Sustainable Environmental Sanitation \& Water Services, Kolkata (Calcutta) India, 18-22, November 2002.

- Maher Al-Jabari and Hassan Sawalha, Experimental Investigation of FlocculationSedimentation Process Design Used in Stone Cutting Plants in Palestine, Jordan International Chemical Engineering Conference IV, vol. I, page 109-133, 22-24, Jordan University of Science and Technology, Amman, Jordan, (September 2002).

- Magdalena Svanstrom, Hassan Sawalha, Nadeem Ali, Sayed Ashraf and Tatjana Karpenja, Supercritical water oxidation of the sewage sludge from Reyaverket wastewater treatment plant, Gothenburg, Sweden, Young scientist conference, Krakow, Poland, May 2004.

- Hassan Sawalha, Ruud den Adel, Paul Venema, Arjen Bot, Eckhard Flöter and Erik van der Linden, Structuring of vegetable oils by combinations of oryzanol and sitosterol, 8th Euro Fed Lipid Congress, 21-24 November 2010, Munich, Germany.

- Hassan Sawalha, Paul Venema, Arjen Bot, Eckhard Flöter and Erik van der Linden, Selfassembly process of $\gamma$-oryzanol $+\beta$-sitosterol fibril formation in edible oil organogels, 1 st International Congress on Food Technology, 03-06 November 2010 Antalya, Turkey.

- Hassan Sawalha, Klazina Kooiman, Nico de Jong, Marcel Böhmer; Karin Schroën, Preparation of polymeric microcapsules for application as ultrasound contrast agents and for ultrasound-mediated delivery of lipophilic drugs, COST action D43, colloid and interface chemistry for nanotechnoloy. Special Session: Colloids for Pharmaceutical Applications., 29-31 March 2011, Madrid, Spain

\section{LANGUAGES}

$\begin{array}{ll}\text { Arabic: } & \text { mother tongue } \\ \text { English: } & \text { fluent } \\ \text { Dutch: } & \text { good }\end{array}$

\section{REFERENCES}

Available upon request 